\title{
Social Anthropology avant la lettre: The Economic Enlightenment Perspective on Traditional Uses of Wetlands
}

\author{
Martin Stuber
}

The period from the late 18th to the mid-19th century is a distinctive era for scientific ethnographic writing. ${ }^{1}$ The research literature on the history of this discipline connects these essential origins of social anthropology mainly to the great, global scientific expeditions of James Cook (1728-1779) and Louis Antoine de Bougainville $(1729-1811) .^{2}$ By contrast, I have adopted a complementary approach, along the lines of Alix Cooper's Inventing the Indigenous. ${ }^{3}$ My research grew out of the exact descriptions of the traditional economy, which today continue to be a main empirical interest of the disciplinary fields of "cultural anthropology," "social anthropology," "ethnology" and "folklife studies" ("Volkskunde, Völkerkunde"). ${ }^{4}$ Such records of traditional economic practices were kept not only in the context of so-called global expeditions but on a larger scale also in the context of Economic Enlightenment ("Ökonomische Aufklärung”) which, since the mid-18th century, gradually covered all of Europe.

A constitutive element of Economic Enlightenment is the systematic development of knowledge stocks for the purposeful exploitation of resources in

1 This chapter is based on: Martin Stuber and Matthias Bürgi, Vom "eroberten Land" zum Renaturierungsprojekt. Geschichte der Feuchtgebiete in der Schweiz seit 1700 (Bern, Stuttgart, Wien: Haupt Verlag, 2018), 19-43.

2 Harry Liebersohn, "Scientific Ethnography and Travel, 1750-1850," in History of Science, vol. 7, The Modern Social Sciences, ed. Theodore M. Porter and Dorothy Ross (Cambridge, New York: Cambridge University Press, 2003), 100.

3 Alix Cooper, Inventing the Indigenous: Local Knowledge and Natural History in Early Modern Europe (Cambridge, New York: Cambridge University Press, 2007).

4 Adam Kuper, "Anthropology," in History of Science, vol.7, The Modern Social Sciences, ed. Theodore M. Porter and Dorothy Ross (Cambridge, New York: Cambridge University Press, 2003), 354 . 
view of a comprehensive modernisation of agriculture and forestry. ${ }^{5}$ However, Economic Enlightenment cannot be reduced to the modernistic view. Indeed, the reformers also describe the rural economy negatively, as an economy too heavily based on tradition, in order to make their own modernisation goals look brighter. Furthermore, reformers were also interested in the exact knowledge of the rural economy to improve the coherence of their reforms. These attempts to view rural society from the inside reveal these reformers as social anthropologists avant la lettre. In many respects, their observations are in line with ethnographic reports and lay the foundations for a contemporary reconstruction of the traditional economy of rural society.

The German historian Rainer Beck developed the concept of "natural economy" ("Naturale Ökonomie") providing examples from Bavaria in the 18th and early 19th centuries: rural societies were dependent on what their efforts produced within their regions year after year, in accordance with the metabolism of nature, and on the amount of energy they were able to reproduce. According to Beck's micro-historical analyses, in this context we must focus not only on areas of intensive agriculture, but also on fringe and outside areas. For example, wetlands, which we are going to draw attention later, were anything but an underused resource in the "natural economy." On the contrary, they were an indispensable complement to more intensively cultivated fields near the villages. ${ }^{6}$

Among the many economic-patriotic societies of Switzerland, the Economic Society of Bern, founded by patricians in 1759, was considered the most important one already at the time. This was due mostly to the quality of its bilingual publication organ, which was read both in the German- and the French-speaking regions. ${ }^{7}$ The Economic Society saw the exact and spatially

5 Marcus Popplow, ed., Landschaften agrarisch-ökonomischen Wissens. Strategien innovativer Ressourcennutzung in Zeitschriften und Sozietäten des 18. Jahrhunderts (Münster: Waxmann, 2010), 3-5; Koen Stapelbroek and Jani Marjanen, eds., The Rise of Economic Societies in the Eighteenth Century: Patriotic Reform in Europe and North America (Basingstoke: Palgrave Macmillan, 2012).

6 Rainer Beck, Naturale Ökonomie. Unterfinning: Bäuerliche Wirtschaft in einem oberbayerischen Dorf des frühen 18. Jahrhunderts (Munich, Berlin: Deutscher Kunstverlag, 1986); Beck, Ebersberg oder das Ende der Wildnis. Eine Landschaftsgeschichte (Munich: C. H. Beck, 2003); Rita Gudermann, Morastwelt und Paradies. Ökonomie und Ökologie in der Landwirtschaft am Beispiel der Meliorationen in Westfalen und Brandenburg (1830-1880) (Paderborn: Schöningh, 2000), 74-78.

7 Martin Stuber, Peter Moser, Gerrendina Gerber-Visser, and Christian Pfister, eds., Kartoffeln, Klee und kluge Köpfe. Die Oekonomische und Gemeinnützige Gesellschaft des Kantons Bern OGG (1759-2009) (Bern, Stuttgart, Wien: Haupt Verlag, 2009); Regula Wyss and Martin Stuber, 
differentiated mapping of the country as its crucial starting point. ${ }^{8}$ Firstly, the Society organised a continuous and standardised network of meteorological stations; ${ }^{9}$ secondly, it drew up inventories of the current and the potential plant resources of the territory, ${ }^{10}$ thirdly, by means of a total of 48 Topographic Descriptions covering each region it recorded the current state of the population, of agriculture, of trades as well as commerce and, based on this, estimated the existing potential for development. ${ }^{11}$ How comprehensive the recording of the regionally differentiated agricultural landscapes designed to be becomes obvious from the work programme of the Economic Society of Bern (1762) which, on 54 printed pages, lists a total of 416 research questions structured into five categories, namely natural history, population, agriculture, trade, and commerce. $^{12}$

"Paternalism and Agricultural Reform. The Economic Society of Bern in the Eighteenth Century," in The Rise of Economic Societies in the Eighteenth Century, ed. Stapelbroek and Marjanen, 157-81.

8 See Alix Cooper, “The Possibilities of the Land': The Inventory of 'Natural Riches' in the Early Modern German Territories," in Oeconomies in the Age of Newton, ed. Margret Schabas and Neil de Marchi (Durham, London: Duke University Press , 2003), 129-53; Inventing the Indigenous, 116-51 (chapter 4: The Nature of the Territory); Torsten Meyer and Marcus Popplow, "To employ each of Nature's Products in the most Favorable Way possible' - Nature as a Commodity in Eighteenth Century German Economic Discourse," Historical Social Research 29, no. 4 (2004).

9 Christian Pfister, Agrarkonjunktur und Witterungsverlauf im westlichen Schweizer Mittelland zur Zeit der ökonomischen Patrioten 1755-1797. Ein Beitrag zur Umwelt- und Wirtschaftsgeschichte des 18. Jahrhunderts (Bern: Lang Druck, 1975), 160-62.

10 Martin Stuber and Luc Lienhard, "Nützliche Pflanzen. Systematische Verzeichnisse von Wild- und Kulturpflanzen im Umfeld der Oekonomischen Gesellschaft Bern," in Nützliche Wissenschaft und Ökonomie im Ancien Régime. Akteure, Themen, Kommunikationsformen, ed. André Holenstein, Martin Stuber, and Gerrendina Gerber-Visser (Heidelberg: Palatina, 2007).

11 Gerrendina Gerber-Visser, Die Ressourcen des Landes: Der ökonomisch-patriotische Blick in den Topographischen Beschreibungen der Oekonomischen Gesellschaft Bern (1759-1855) (Baden: hier + jetzt, 2012), 36o-61.

12 "Entwurf der vornehmsten Gegenstände der Untersuchungen, die zur Aufnahme des Feldbaues, des Nahrungsstandes und der Handlung abzielen sollen," in Abhandlungen und Beobachtungen durch die ökonomische Gesellschaft zu Bern gesammelt, 1. Stück (1762); see Martin Stuber, "Die Entdeckung der Landschaft als territoriale Ressource," in Geschichte der Landschaft in der Schweiz: Von der Eiszeit bis zur Gegenwart, ed. Jon Mathieu, Norman Backhaus, Katja Hürlimann, and Matthias Bürgi (Zurich: Orell Füssli, 2016); Simona Boscani Leoni, "Queries and Questionnaires. Collecting Local and Popular Knowledge in 17th and 18th Century Europe," in Wissenschaftsgeschichte und Geschichte des Wissens im Dialog - Connecting Science and Knowledge, ed. Kaspar von Greyerz, Silvia Flubacher, and Philipp Senn (Göttingen: V\&R unipress, 2013). 
This economic-patriotic work programme includes a number of items on wetlands. Basically, one sought to establish kinds and origin of the various wetlands. How did these wetlands develop, in which ways were they supplied with water, and where did the water drain off? Furthermore, one was interested in their current economic significance: How could they be exploited? What would be the best way of cultivating wet meadows? Which trees or bushes grow best on wet grounds, each according to a different climate?13

A number of research questions concerned the conversion of wetlands into farmland, which could be used for agriculture or forestry. How could, "by way of draining the bogs, and by way of improving low or wet grounds, efforts and expenses be reduced?" Are there local gravel pits "for the improvement of wet grounds?" When laying out the area of the "drained bogs" for cultivation for the first time, what must be taken into consideration if they are supposed to be turned into artificial pastures, vegetable or herb gardens or are meant for any other kind of "field crops"?

In the economic-patriotic work programme, wetlands, though not explicitly mentioned, belong to the superior context of the desired population growth, which was considered a sign of good government. Because of demographic interests, one did not want to know only the essential demographic variables for each region - marriages, births and deaths - but also the ratio of cultivated ("kultiviertes") to fallow ("ungebautes") land. If one is aware of the fact that the wetlands accounted for a significant portion of "fallow" land, it becomes immediately obvious how relevant the following research questions are for our topic. What is the ratio of population numbers to acreage of cultivated land? Of what kind is the fallow land in each individual district? Could it not be cultivated? And which crops could best be grown there? What is the price of fallow land ${ }^{14}$ All this refers to the fact that an increase in cultivated land by draining wetlands was believed to have an immediately positive impact on the desired population growth - and consequently on the desired growth of the national economy.

The many observations and functional connections of the "natural economy" on wetlands recorded by the Economic Society of Bern shall now be structured and presented according to the various landscapes. Through the Topographic Descriptions ("Topographische Beschreibungen") of the Economic Society of Bern, I reach back to a stock of sources which were opened up and analysed by Gerrendina Gerber-Visser in the context of her PhD thesis. ${ }^{15}$ The records

\footnotetext{
13 "Entwurf der vornehmsten Gegenstände der Untersuchungen," 20-21.

14 Ibid., 17-19.

15 Gerber-Visser, Die Ressourcen des Landes.
} 
were made first by local pastors. The quality of their observations rests on the fact that, on the one hand, they had been educated in the cities; and on the other hand that their official position as rural priests made them were well acquainted with the local situations. ${ }^{16}$

Vicar Albrecht Stapfer (1722-1798) is a case in point. In his award-winning The Best Way of Turning all Kinds of wetlands into Cultivated Land (1761), he proves to be a good observer of the specific "natural economy" of Saanenland. He explains the logic of the local exploitation system in detail, which keeps many rural people from draining their boggy meadows. For, only if they leave their wetlands in the natural state can they be provided, without effort, with sufficient fodder for their young cattle and horses also in the future. In addition, the draining of the Saanen bogs as well as of the boggy areas near Zweisimmen and Boltigen would affect the meadows. This, he said, was because in their current state wetlands grew an astonishing amount of reed and bad timothy, which - since grain is not grown there - is indispensable as a bed for the cattle which then, together with dung, also serves for fertilising the grassland. ${ }^{17}$

We find additional hints in the Topographic Descriptions of other valleys of the Bernese Oberland. In Grindelwald, the pastor notes that people use sacks stuffed with litter as mattresses. ${ }^{18}$ The Vicar of St Stephan observes that, apart from maple leaves, most of all litter is used for beds in the stables. ${ }^{19}$ The Vicar of Sigriswil comments critically on the many wetland areas, although just a few drainage ditches would easily help; on the common land, about half an hour

16 Regula Wyss and Gerrendina Gerber-Visser, "Formen der Generierung und Verbreitung nützlichen Wissens. Pfarrherren als lokale Mitarbeiter der Oekonomischen Gesellschaft Bern," in Nützliche Wissenschaft und Ökonomie im Ancien Régime. Akteure, Themen, Kommunikationsformen, ed. André Holenstein, Martin Stuber, and Gerrendina Gerber-Visser (Heidelberg: Palatina, 2007).

17 [Albrecht Stapfer], "Abhandlung von Auströcknung der Möser, Sümpfe, Moräste und Nuzbarkeit derselben," in Der Schweitzerischen Gesellschaft in Bern Sammlungen von landwirthschaftlichen Dingen, 2. Stück (1761); see Martin Stuber and Matthias Bürgi, Hüeterbueb und Heitisträhl. Traditionelle Formen der Waldnutzung in der Schweiz 1800 bis 2000 (Bern, Stuttgart, Wien: Haupt Verlag, 2011), 89-93.

18 [Friedrich Kuhn and Bernhard Friedrich Kuhn], "Versuch einer Beschreibung des Grindelwaldthales [1. Teil]," Magazin für die Naturkunde Helvetiens 1 (1787).

19 Johann Heinrich Schmid, Beschreybung des Kirchspiehls St. Stephan im Simmenthal, Manuscript (1783): Burgerbibliothek Bern: GA Oek. Ges. 123 (5). Transcription Gerrendina Gerber-Visser. 


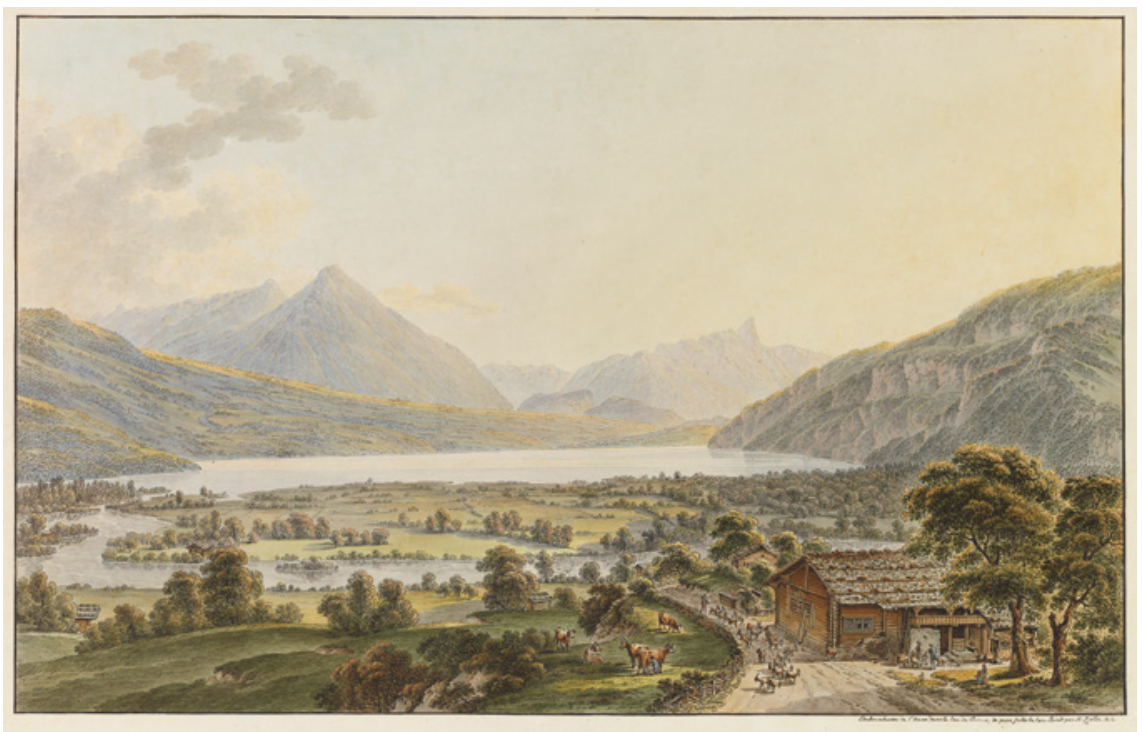

FIGURE 8.1 River Mouth of the Aare, near Interlaken, 1812 - H. Rieter, Schweizerische Nationalbibliothek, Bern, Sammlung Gugelmann

uphill from the village, nobody bothers to drain so many wide, boggy places with the help of ditches, to prevent creeks and ditches being swept away. ${ }^{20}$

The Vicar of Meiringen, too, is critical of the common land. Regarding the Haslital, he notes pointedly that there were so many acres of wet ground where only litter grew that the horses there would not take to a better quality, so used they were to the existing bad fodder. People, he claimed, would at once be motivated to improve this situation if the common lands, most of which were wet ground, were equally distributed among the people as their private property. ${ }^{21}$

Vicar Johann Rudolf Nöthiger (1739-1826) in his Physisch-topographische Beschreibung der Kirchgemeinde Gsteig bei Interlaken (1783) argues in a similar way. The large bog area, he says, would turn into exceptionally fertile lands producing abundant crops if it were privately owned and everybody could improve their own plot and use it for their own benefit as they liked. However, as the privatisation of the common lands had not started yet, Nöthiger states,

$20 \quad$ Gottlieb Jakob Kuhn, "Versuch einer oekonomisch-topographischen Beschreibung der Gemeinde Sigriswyl," Alpina 3 (1808).

21 [Johannes Sprüngli], "Beschreibung des Hasle-Lands im Canton Bern [1. Teil]," in Der Schweitzerischen Gesellschaft in Bern Sammlungen von landwirthschaftlichen Dingen, 4. Stück (1760); "Von dem Haslethal [2. Teil]," in Abhandlungen und Beobachtungen durch die ökonomische Gesellschaft zu Bern gesammelt, 4. Stück (1762). 
with regret, that the various parts of the bogs are subject to a variety of different, partly overlapping, rights. For example, the "Auermoos" is subject to the common rights of the village community of Aarmühle which, however, as the right to graze horses, may be exercises only in spring, from early May to the end of June, as well as in autumn from September 14th to October 16th. What grows in the meantime is the property of several private owners from the communities in the vicinity and is divided into plots of land or "Meder," which may be inherited, purchased, subdivided into smaller plots. The size of these "Meder" may vary greatly and yield between one and thirty loads of litter fodder. The Wilderswilermoos, on the other hand, is jointly owned by the two village communities of Matten and Wilderswil, only the latter being entitled to grazing in spring and autumn. The Monastery of Interlaken had likewise acquired ownership of two "Meder."22

\section{3}

\section{Aare and Gürbe Valleys}

The great significance of the wetlands for the local "natural economy" becomes also obvious from Vicar Samuel Massés (1704-1782) manuscript on the parish of Belp, which owns a large wetland area. ${ }^{23}$ According to Massé, the bog area is flooded twice a year by the Gürbe river, which is swollen by rain and meltwater, making the fodder inedible because of evil-smelling morass and sand. At its southern end, it provides meagre grass and litter for horses and oxen, only in relatively dry periods. The bog area along the Aare river provides fodder of better quality, which is good for all kinds of horses and cattle. On the question of how the population is affected by the wetlands, Massé's conclusion is ambivalent. On the one hand, making up most of the common land they are an important economic resource most of all for the poor. On the other hand, Massé connects them to a number of different diseases which he believes to be caused by the wet state of the bog and the dwelling places sinking deeply into

\footnotetext{
22 Johann Rudolf Nöthiger, Physisch-topographische Beschreibung der Kirchgemeinden Unterseen, Habkern und Beatenberg, Manuscript (1783): Burgerbibliothek Bern: GA Oek. Ges. 123 (11). Transcription Gerrendina Gerber-Visser.

23 Massé, Samuel, Antwortlicher Bericht über die vorgeschlagenen Fragen der Oeconomischen Gesellschaft, soweit dieselben dem Bezirk der Kirchgemeinde Belp betreffen mögen, Manuscript (1762): Burgerbibliothek Bern: GA Oek. Ges. 123 (1). Transcription Gerrendina Gerber-Visser; siehe Melanie Salvisberg, Der Hochwasserschutz an der Gürbe: Eine Herausforderung für Generationen (1855-2010) (Basel: Schwabe Verlag, 2017), 68-75.
} 


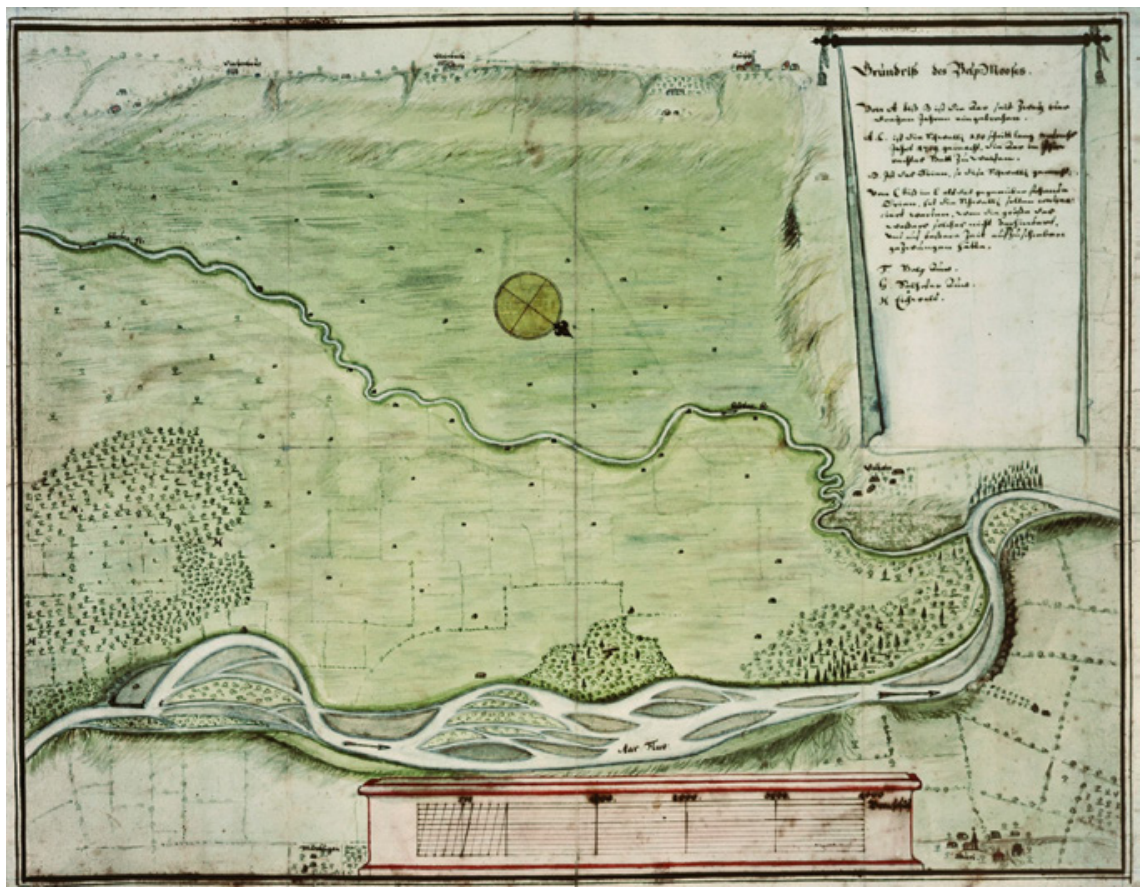

FIGURE 8.2 Plan of the Belp Bog (Grundriss des Belp-Mooses), 1709 - Staatsarchiv des Kantons Bern: AA IV 2157

the ground. The bog air, he says, causes scurvy and frequent toothache, bad hearing, and weakness of limbs. ${ }^{24}$

According to the description given by theologian and naturalist Samuel Jakob Wyttenbach (1748-1830), also in the community of Gurzelen, about 15 kilometres upriver, most of the lands are of a bog nature. Whereas the meadows of the share owners are on grass land, all common lands and common property are on bog or peat lands. Where the bog is too deep and the grass is bad the litter growing there is auctioned every year. ${ }^{25}$ For a long time the boggy land at Gurzelen was only of little value, until a few years ago one acre did not sell for more than 20 Crowns. Very recently, however, precisely the prices for these grounds started rising, a trend that Wyttenbach connects to the fact that cultivatable boggy areas are perfectly suitable for cabbage gardens, that the

24 Massé, Antwortlicher Bericht über die vorgeschlagenen Fragen der Oeconomischen Gesellschaft; see Sinja Clavadetscher, "Die Topographischen Beschreibungen zweier Moosgebiete: Belp und Kerzers" (Proseminararbeit University of Bern, 2015), 9-10, 15-18.

25 Jakob Samuel Wyttenbach, Beschreibung der Pfarrgemeinde Gurzelen, Manuscript (1776): Burgerbibliothek Bern: Mss. Hist. Helv. Xx 9 C 2o. Transcription Gerrendina Gerber-Visser. 
"Thurnen cabbage" growing there is sold to Bern in large amounts and generates considerable profits for farmers. ${ }^{26}$

\section{$4 \quad$ Seeland}

In the Oekonomische Beschreibung des Kirchspieles Kerzers (1763) by the Vicar David Albrecht Bolz (1713-1782), the longest section of the whole work, is devoted to the wetlands. This is in line with their significance for local cattle farming, which Bolz explains by comparing the five village communities. As they are located farther away from the Grosses Moos, in Golaten, Gurbrü and Wileroltigen, there is not much horse breeding and only little cattle husbandry; horses and cattle must be grazed in the little fertile woods and meadows. Kerzers and Fräschels, on the other hand, being located near the Grosses Moos, are capable of large-scale horse breeding and can have large cattle herds. As most meadows are not privately owned, one makes use of the rights to "common meadows" from whose crops even a poor man can feed at least two heads of cattle over the winter.

However, the bog meadow is a health concern, in particular at the height of summer. According to Bolz, the water in the ditches, which starts smelling in the heat, is a major cause of widespread cattle disease in the area. In the hot summer of 1761, near Fräschels many cows, oxen and horses died from anthrax, which must doubtlessly be blamed on the poisonous mists that often rise from the ground like rot, and on the rotten water. Bolz, however, does not mention any negative effects on people. On the contrary, he classifies the vast bog area under the "hardenings" that make the local people healthy, strong, cheerful, hard-working. And when in a cold, wet spring they often struggle to chase their cattle on the bog meadows while standing in waist-deep morass and water, they simply change their clothes, which happens every day, and they remain in good health while doing so. ${ }^{27}$

For the sake of completeness, here we may refer to two other Topographic Descriptions of Seeland written at the same time. At Bözingen - today a quarter of the City of Biel - in the direction of Pieterlen there is a bog of about one hour's length which has developed where the waters of Leber- and Büttenberg

\footnotetext{
26 Ibid.

27 David Albrecht Bolz, "Oekonomische Beschreibung des Kirchspieles Kerzers," in Abhandlungen und Beobachtungen durch die ökonomische Gesellschaft zu Bern gesammelt, 1. Stück (1763); see Clavadetscher, "Die Topographischen Beschreibungen zweier Moosgebiete," $11-15$.
} 
collect and cannot drain. One part of the bog is let to the community people for a yearly rent, as hay rights; the other part is the bog gardens where barley, cabbage and other vegetables are grown. The author, the book printer Niklaus Heilmann (1739-1817) from Biel, views the forgoing of collective rights as the key to an improved cultivation of bog land. For two reasons. To begin with, by doing so the community people would no longer lose the urgently needed dung, which is lost during the eight months of grazing their cattle on the common meadows, but could collect it for their fields; secondly, if so, owners would no longer be satisfied with what nature provides voluntarily but would of their own accord diligently and carefully improve their share. ${ }^{28}$

Even 70 years later, wetlands are omnipresent in the Beschreibung der Kirchgemeinde Gampelen written by Judge Gottlieb Stauffer (1786-1882). Whereas in most places the ground of the forests, fields and vineyards - all of them located in a hilly area - is clay, in single cases also sandy, the meadows on low ground are mostly "mossy and boggy" and about one-fifth of the area is periodically flooded. If these floods last only for a short time, they have a "beneficial" effect, however they cause extraordinary damage in those years when they last longer. After the two-year flood of $1816 / 17$, two decades later both the fodder yield and grass for grazing were still lower than before.

Similarly, at Gampelen, the utilisation of the Grosses Moos goes beyond the use of meadows and litter. For example, the garden plants for the weekly markets in Neuchâtel are not only grown around the houses but also in the bog gardens, which results in constant losses for many people. Particularly after wet years a considerable number of frogs are caught; whereas the thighs of the hind legs are sold to merchants at Muntelier, the other parts of the frogs make good swine fodder a small bucket is sold for about 2.5 to 3 Batzes. Until recently, leeches ("Blutegeln") were collected in great numbers and sold to Neuchâtel; unfortunately, now they are almost extinct. This seems to have been caused by their high prices, no spawn being spared. Moreover in the Grosses Moos, during the periodical floods, often considerable amounts of fish are caught

28 [Heilmann, Niklaus], "Topographisch und Oekonomische Beschreibung der Landschaft um Biel gelegen," in Abhandlungen und Beobachtungen durch die ökonomische Gesellschaft zu Bern gesammelt, 4. Stück (1766); similarly: Abraham Pagan: "Versuch einer Oekonomischen Beschreibung der Graffschaft oder Landvogtey Nidau im Canton Bern," in Abhandlungen und Beobachtungen durch die ökonomische Gesellschaft zu Bern gesammelt, 4. Stück (1761): The best yield from the "Möösern oder Morästen" is the "Beünden" (small gardens) where kitchen herbs, cabbage, hemp and flax are grown. Most of them are harvested or mown after a certain time of the year. Of them we must positively distinguish the single shares separated from the common lands and meadows: "These plots torn from the service of grazing illustrate well the different yield, and what unlimited diligence may contribute to the fertility of lands." 


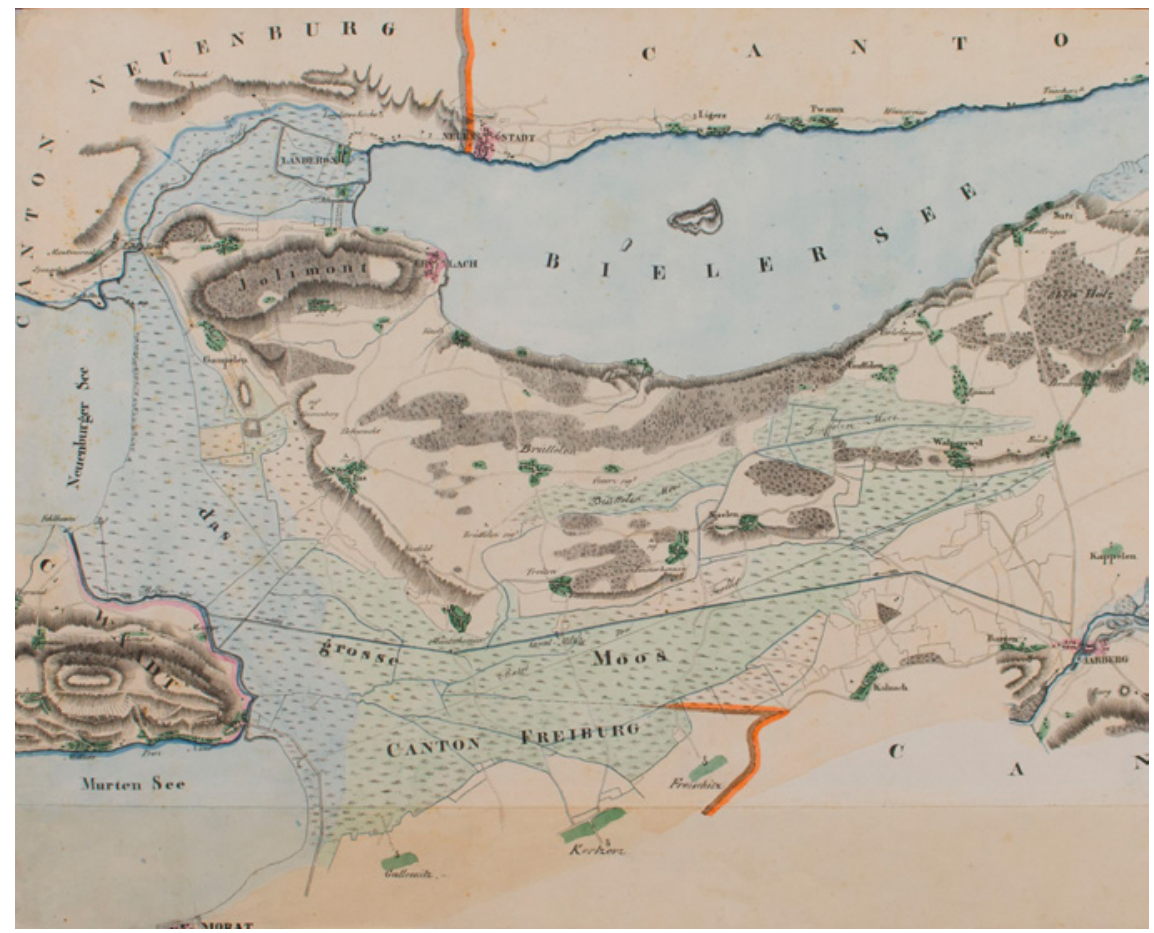

FIGURE 8.3 General Map of the Jura Water Bodies (General Charte der Jura Gewässer), 1816/17, F. Trechsel; J. Oppikofer - Staatsarchiv des Kantons Bern (Atlanten 21)

with the help of nets or six-tined forks, which are then sold to the merchants of Muntelier or Lüscherz who sell them on in Solothurn, Bern, Fribourg and Neuchâtel. ${ }^{29}$

\section{5}

\section{Conclusion}

For the reformers, the stocktaking of the rural economy served, on the one hand, as a negative backdrop for their criticism, and on the other hand as a basis for working out reform strategies. This double motivation yielded early social-anthropologic observations, which may be summarised in three points:

29 Gottlieb Stauffer, Beschreibung der Kirchgemeinde Gampelen und des in derselben liegenden ehemaligen Klosters St. Johannsen, Manuscript (1835/1839): Burgerbibliothek Bern: GA Oek. Ges. 125 (18); GA Oek. Ges. 125 (20). Transcription: Gerrendina Gerber-Visser. 
1. The economic significance of the wetlands was observed and recorded in detail: being an extensive way of land use, it allowed for some minimum animal husbandry even for poorer households, which were not dependent on cash and individual land property.

2. The observations are not limited to the traditional economy; indeed the reformers also perceived dynamic elements, such as the harvesting of litter used to meet the growing demand for beds as a result of increasing stable feeding in summer, a key element of the modernisation of agriculture. Frogs and leeches caught in the wetlands were supplied the growing urban markets of the cities of Bern, Fribourg, Neuchâtel and Solothurn; and so were vegetables increasingly cultivated on formerly boggy ground.

3. The "natural economy" was not considered in isolation but as embedded in institutions. Most wetlands were common property, which the reformers criticized as being an obstacle for innovation. From their point of view, only private interests would motivate the necessary improvements. In the long run, this criticism is somewhat ironic: from an ecological point of view, today it is precisely in the absence of those collective methods of exploitation - mowing and grazing - that wetlands silt up. Today, these ways of utilisation must be imitated by complex - and appropriately costly - environmental protection measures. ${ }^{30}$

\section{Acknowledgements}

This contribution is based on: Martin Stuber and Matthias Bürgi, Vom "eroberten Land" zum Renaturierungsprojekt. Geschichte der Feuchtgebiete in der Schweiz seit 1700 (Bern, Stuttgart, Wien: Haupt Verlag, 2018), 19-43. I wish to thank Gerrendina Gerber-Visser (Bern) for kindly handing over the transcriptions of the unpublished Topographical Descriptions to me; and to Mirko Wittwar (Morsbach, D), for his careful translation in English.

$30 \quad$ See Meinrad Küchler, Moore der Schweiz. Zustand, Entwicklung, Regeneration (Bern, Stuttgart, Wien: Haupt Verlag, 2018); Meinrad Küchler and Helen Küchler, "Entwicklung der Vegetation in geschützten Moorflächen, 1995-2007," in Vom "eroberten Land" zum Renaturierungsprojekt, ed. Martin Stuber and Matthias Bürgi (Bern, Stuttgart, Wien: Haupt Verlag, 2018). 


\section{Bibliography}

\section{Manuscripts}

Massé, Samuel. Antwortlicher Bericht über die vorgeschlagenen Fragen der Oeconomischen Gesellschaft, soweit dieselben dem Bezirk der Kirchgemeinde Belp betreffen mögen. Manuscript (1762): Burgerbibliothek Bern: GA Oek. Ges. 123 (1). Transcription Gerrendina Gerber-Visser.

Nöthiger, Johann Rudolf. Physisch-topographische Beschreibung der Kirchgemeinden Unterseen, Habkern und Beatenberg. Manuscript (1783): Burgerbibliothek Bern: GA Oek. Ges. 123 (11). Transcription Gerrendina Gerber-Visser.

Schmid, Johann Heinrich. Beschreybung des Kirchspiehls St. Stephan im Simmenthal. Manuscript (1783): Burgerbibliothek Bern: GA Oek. Ges. 123 (5). Transcription Gerrendina Gerber-Visser.

Stauffer, Gottlieb. Beschreibung der Kirchgemeinde Gampelen und des in derselben liegenden ehemaligen Klosters St. Johannsen. Manuscript (1835/1839): Burgerbibliothek Bern: GA Oek. Ges. 125 (18); GA Oek. Ges. 125 (20). Transcription: Gerrendina Gerber-Visser.

Wyttenbach, Jakob Samuel, Beschreibung der Pfarrgemeinde Gurzelen. Manuscript (1776): Burgerbibliothek Bern: Mss. Hist. Helv. XX 9 C 20. Transcription Gerrendina Gerber-Visser.

\section{Printed Sources}

Bolz, David Albrecht. "Oekonomische Beschreibung des Kirchspieles Kerzers." In Abhandlungen und Beobachtungen durch die ökonomische Gesellschaft zu Bern gesammelt. 1. Stück (1763), 69-89.

"Entwurf der vornehmsten Gegenstände der Untersuchungen, die zur Aufnahme des Feldbaues, des Nahrungsstandes und der Handlung abzielen sollen." In Abhandlungen und Beobachtungen durch die ökonomische Gesellschaft zu Bern gesammelt. 1. Stück (1762), 1-54.

Kuhn, Gottlieb Jakob. "Versuch einer oekonomisch-topographischen Beschreibung der Gemeinde Sigriswyl." Alpina 3 (1808): 116-69.

[Heilmann, Niklaus]. "Topographisch und Oekonomische Beschreibung der Landschaft um Biel gelegen." In Abhandlungen und Beobachtungen durch die ökonomische Gesellschaft zu Bern gesammelt. 4. Stück (1766), 53-82.

[Kuhn, Friedrich and Bernhard Friedrich Kuhn]. "Versuch einer Beschreibung des Grindelwaldthales [1. Teil]." Magazin für die Naturkunde Helvetiens 1 (1787): 1-28.

Pagan, Abraham. "Versuch einer Oekonomischen Beschreibung der Graffschaft oder Landvogtey Nidau im Canton Bern." In Abhandlungen und Beobachtungen durch die ökonomische Gesellschaft zu Bern gesammelt. 4. Stück (1761), 785-859. 
[Sprüngli, Johannes]. "Beschreibung des Hasle-Lands im Canton Bern [1. Teil]." In Der Schweitzerischen Gesellschaft in Bern Sammlungen von landwirthschaftlichen Dingen. 4. Stück (1760), 859-85.

[Stapfer, Albrecht]. "Abhandlung von Auströcknung der Möser, Sümpfe, Moräste und Nuzbarkeit derselben." In Der Schweitzerischen Gesellschaft in Bern Sammlungen von landwirthschaftlichen Dingen. 2. Stück (1761), 243-306.

"Von dem Haslethal [2. Teil]." In Abhandlungen und Beobachtungen durch die ökonomische Gesellschaft zu Bern gesammelt. 4. Stück (1762), 130-43.

\section{Literature}

Beck, Rainer. Naturale Ökonomie. Unterfinning: Bäuerliche Wirtschaft in einem oberbayerischen Dorf des frühen 18. Jahrhunderts. Munich, Berlin:Deutscher Kunstverlag, 1986.

Beck, Rainer. Ebersberg oder das Ende der Wildnis. Eine Landschaftsgeschichte. Munich: C. H. Beck, 2003.

Boscani Leoni, Simona. "Queries and Questionnaires. Collecting Local and Popular Knowledge in $17^{\text {th }}$ and 18th Century Europe." In Wissenschaftsgeschichte und Geschichte des Wissens im Dialog - Connecting Science and Knowledge, edited by Kaspar von Greyerz, Silvia Flubacher, and Philipp Senn, 187-208. Göttingen: V\&R unipress, 2013.

Clavadetscher, Sinja. "Die Topographischen Beschreibungen zweier Moosgebiete: Belp und Kerzers." Proseminararbeit, University of Bern, 2015.

Cooper, Alix. "The Possibilities of the Land': The Inventory of 'Natural Riches' in the Early Modern German Territories." In: Oeconomies in the Age of Newton, edited by Margret Schabas, Neil de Marchi, 129-53. Durham, London: Duke University Press, 2003 .

Cooper, Alix. Inventing the Indigenous: Local Knowledge and Natural History in Early Modern Europe. Cambridge, New York: Cambridge University Press, 2007.

Gerber-Visser, Gerrendina. Die Ressourcen des Landes: Der ökonomisch-patriotische Blick in den Topographischen Beschreibungen der Oekonomischen Gesellschaft Bern (1759-1855). Archiv des historischen Vereins des Kantons Bern 89. Baden: hier + jetzt, 2012.

Gudermann, Rita. Morastwelt und Paradies. Ökonomie und Ökologie in der Landwirtschaft am Beispiel der Meliorationen in Westfalen und Brandenburg (1830-1880). Paderborn: Schöningh, 2000.

Küchler, Meinrad and Helen Küchler. "Entwicklung der Vegetation in geschützten Moorflächen, 1995-2007." In Vom "eroberten Land" zum Renaturierungsprojekt. Geschichte der Feuchtgebiete in der Schweiz seit 1700, edited by Martin Stuber and Matthias Bürgi, 242-54. Bern, Stuttgart, Wien: Haupt Verlag, 2018. 
Küchler, Meinrad et al. Moore der Schweiz. Zustand, Entwicklung, Regeneration. Bern, Stuttgart, Wien: Haupt Verlag, 2018.

Kuper, Adam. "Anthropology." In History of Science, vol.7, The Modern Social Sciences, edited by Theodore M. Porter and Dorothy Ross, 354-78. Cambridge, New York: Cambridge University Press, 2003.

Liebersohn, Harry. "Scientific Ethnography and Travel, 1750-1850." In History of Science, vol. 7, The Modern Social Sciences, edited by Theodore M. Porter and Dorothy Ross, 100-12. Cambridge, New York: Cambridge University Press, 2003.

Meyer, Torsten and Marcus Popplow. "To employ each of Nature's Products in the most Favorable Way possible' - Nature as a Commodity in Eighteenth Century German Economic Discourse." Historical Social Research 29, no. 4 (2004): 4-40.

Pfister, Christian. Agrarkonjunktur und Witterungsverlauf im westlichen Schweizer Mittelland zur Zeit der ökonomischen Patrioten 1755-1797. Ein Beitrag zur Umwelt- und Wirtschaftsgeschichte des 18. Jahrhunderts. Bern: Lang Druck, 1975.

Popplow, Marcus, ed. Landschaften agrarisch-ökonomischen Wissens. Strategien innovativer Ressourcennutzung in Zeitschriften und Sozietäten des 18. Jahrhunderts. Münster: Waxmann 2010.

Salvisberg, Melanie. Der Hochwasserschutz an der Gürbe. Eine Herausforderung für Generationen (1855-2010). Basel: Schwabe Verlag, 2017.

Stapelbroek, Koen and Jani Marjanen, eds. The Rise of Economic Societies in the Eighteenth Century: Patriotic Reform in Europe and North America. Basingstoke: Palgrave Macmillan 2012.

Stuber, Martin and Luc Lienhard. "Nützliche Pflanzen. Systematische Verzeichnisse von Wild- und Kulturpflanzen im Umfeld der Oekonomischen Gesellschaft Bern." In Nützliche Wissenschaft und Ökonomie im Ancien Régime. Akteure, Themen, Kommunikationsformen, edited by André Holenstein, Martin Stuber, and Gerrendina Gerber-Visser, 65-106. Heidelberg: Palatina, 2007.

Stuber, Martin, Peter Moser, Gerrendina Gerber-Visser and Christian Pfister, eds. Kartoffeln, Klee und kluge Köpfe. Die Oekonomische und Gemeinnützige Gesellschaft des Kantons Bern OGG (1759-2009). Bern, Stuttgart, Wien: Haupt Verlag, 20o9.

Stuber, Martin and Matthias Bürgi. Hüeterbueb und Heitisträhl. Traditionelle Formen der Waldnutzung in der Schweiz 1800 bis 2000. Bern, Stuttgart, Wien: Haupt Verlag, 2011.

Stuber, Martin. "Die Entdeckung der Landschaft als territoriale Ressource." In Geschichte der Landschaft in der Schweiz. Von der Eiszeit bis zur Gegenwart, edited by Jon Mathieu, Norman Backhaus, Katja Hürlimann, and Matthias Bürgi, 91-104. Zurich: Orell Füssli, 2016.

Stuber, Martin and Matthias Bürgi. Vom "eroberten Land" zum Renaturierungsprojekt. Geschichte der Feuchtgebiete in der Schweiz seit 1700. Bern, Stuttgart, Wien: Haupt Verlag, 2018. 
Wyss, Regula and Gerrendina Gerber-Visser. "Formen der Generierung und Verbreitung nützlichen Wissens. Pfarrherren als lokale Mitarbeiter der Oekonomischen Gesellschaft Bern." In Nützliche Wissenschaft und Ökonomie im Ancien Régime. Akteure, Themen, Kommunikationsformen, edited by André Holenstein, Martin Stuber, and Gerrendina Gerber-Visser, 41-64. Heidelberg: Palatina, 2007.

Wyss, Regula and Martin Stuber. "Paternalism and Agricultural Reform. The Economic Society of Bern in the Eighteenth Century." In The Rise of Economic Societies in the Eighteenth Century, edited by Stapelbroek and Marjanen, 157-81. Basingstoke: Palgrave Macmillan, 2012. 